Article

\title{
Electric Road Systems: Strategic Stepping Stone on the Way towards Sustainable Freight Transport?
}

\author{
Jesko Schulte* (iD) and Henrik Ny \\ Department of Strategic Sustainable Development, Blekinge Institute of Technology, SE-37179 Karlskrona, \\ Sweden; henrik.ny@bth.se \\ * Correspondence: jesko.schulte@bth.se; Tel.: +46-455-385-519
}

Received: 6 March 2018; Accepted: 4 April 2018; Published: 11 April 2018

\begin{abstract}
Electrification of the transport sector has been pointed out as a key factor for tackling some of today's main challenges, such as global warming, air pollution, and eco-system degradation. While numerous studies have investigated the potential of electrifying passenger transport, less focus has been on how road freight transport could be powered in a sustainable future. This study looks at Electric Road Systems (ERS) in comparison to the current diesel system. The Framework for Strategic Sustainable Development was used to assess whether ERS could be a stepping stone on the way towards sustainability. Strategic life-cycle assessment was applied, scanning each life-cycle phase for violations against basic sustainability principles. Resulting sustainability "hot spots" were quantified with traditional life-cycle assessment. The results show that, if powered by renewable energy, ERS have a potential to decrease the environmental impact of freight transport considerably. Environmental payback times of less than five years are achievable if freight traffic volumes are sufficiently high. However, some severe violations against sustainability principles were identified. Still, ERS could prove to be a valuable part of the solution, as they drastically decrease the need for large batteries with high cost and sustainability impact, thereby catalyzing electrification and the transition towards sustainable freight transport.
\end{abstract}

Keywords: Electric Road Systems; sustainable freight transport; life-cycle assessment; E-freight; Strategic Sustainable Development; electric vehicles

\section{Introduction}

Transportation is a necessity and facilitator for people to meet their needs in today's society. At the same time, side effects of the current, fossil-based transport system, such as emissions of carbon dioxide, particulate matters, nitrogen and sulfur oxides, undermine human health as well as eco-system quality [1]. In the EU, the transportation sector accounts for one third of the total energy use and one fifth of all greenhouse gas (GHG) emissions [2]. At the same time, living up to the Paris Agreement requires drastic emission reductions and Europe wants to be the leading region in the transition towards a sustainable society. Electrification of vehicles has been pointed out as a key factor for success, due to zero exhaust emissions in the use phase [3]. However, there are still sustainability constraints in other life-cycle phases [4]. So far, most attention has focused on electric vehicles (EVs) for passenger transport. Still, trucks account for 25\% of GHG-emissions of EU's transport sector [5] and the number of heavy trucks, especially, is increasing more and more [6]. Battery electric vehicles are often regarded as the main solution and several fully electric, battery-powered trucks have been presented to the public, for example the Tesla Semi and the Nikola One. Enabling a heavy truck to drive $800 \mathrm{~km}$ on one charge, however, requires large batteries. Batteries have a substantial sustainability impact during their life-cycle, at least with current designs [7,8]. Also, the substitution of today's global truck fleet with battery-powered freight transport is limited by resource constraints, 
especially considering metals like cobalt and lithium $[9,10]$. In addition, the batteries account for a major part of the vehicle cost, which is one of the largest barriers for the introduction of EVs [11].

Electric Road Systems (ERS)—defined as roads that support dynamic power transfer from the road to vehicles while the vehicles are in motion-could be a supplement to overcoming some of the challenges of battery EVs [12]. Still, it is important to reflect on the original aim of pursuing EV technology, namely making the transition towards a sustainable transport system, and to investigate if and how ERS can contribute to reaching this aim [13]. Previous studies have so far investigated technical aspects of ERS or conducted environmental comparisons based on specific life-cycle stages, focusing on the potential for GHG emission reductions [14]. However, when focusing only on a concept's potential to simply decrease the sustainability impact of a system, a strategic perspective is missing. Hence, the new concept might be better than the existing solution, but may still be incapable of reaching all the way to sustainability and, thereby, prove to be a costly dead end. The purpose of this study is, therefore, to broaden the perspective to investigate the complete life-cycle of ERS infrastructure from a full socio-ecological, strategic sustainability perspective. More specifically, this study aims at providing insights to the following research questions:

1. What is the sustainability impact of overhead line ERS in comparison to the current fossil-powered system?

2. What is the relative importance of different life-cycle phases?

3. Could the introduction of ERS be a strategic stepping stone on the way towards sustainable transport?

By answering these questions, the contribution of this study is (i) the analysis of the complete life-cycle from raw material extraction to end-of-life; (ii) including both the ecological and social dimensions; and (iii) applying a long-term strategic planning perspective by using backcasting from basic principles for sustainability, which is further explained in Section 2.2.

\section{Background}

\subsection{Electric Road Systems}

ERS have emerged as one of few realistic solutions to make freight transport more energy efficient and sustainable [15]. According to the same study, there are two use case scenarios for ERS: they can either be used in closed systems, for example for bus routes or on mining sites, or in open systems (i.e., highways for the general traffic). By electrifying main roads, convenient long-distance transport would be possible, at the same time as allowing the battery size to be relatively small, delivering approximately $150 \mathrm{~km}$ of range depending on how much of the road network that is electrified [11]. Mainly three technical concepts exist, which have been described in more detail in previous studies [11,16]:

i Conductive power supply through overhead lines, similar to trains;

ii Conductive power supply through an electric rail in the road, similar to some subways; and

iii Inductive power supply without any physical contact through electric coils in the road.

For all concepts, research is ongoing and test tracks exist at various places around the world, but they are still far from constituting large-scale commercial systems and have technology readiness levels between three and seven [16]. The concepts differ significantly from each other in many aspects including function, cost and environmental impact. Concept (i) can only be used by high vehicles, for example trucks and buses, while concepts (ii) and (iii) also could be used by passenger battery EVs. However, passenger cars usually travel much shorter distances per day and, therefore, have a much lower need for charging other than home charging. All three concepts require that trucks have an additional source for propulsion, for example, an internal combustion engine, fuel cell, or a small battery. This is necessary as it is only meaningful to electrify the parts of the road network that have 
high traffic flows. In addition, sections like bridges or interceptions might not be possible to electrify. Therefore, a hybrid solution is needed for driving on the non-electrified sections. As usually only one lane has access to the ERS, another power supply is also needed for overtaking on the non-electrified lane. In addition, not being completely dependent on electricity supply from the ERS increases the system's resilience to malfunction and power failure considerably.

So far, most scientific literature has focused on inductive power transfer (IPT), for example [13,17-22], and test tracks are in operation in, among other places, South Korea and Italy [23]. Opinions regarding costs vary, but in Europe it is considered to be the most expensive of the three concepts [11,24,25]. Although IPT has several advantages, there is also some uncertainty regarding health effects of electromagnetic fields $[26,27]$ and as to whether the technology is robust enough for safe and reliable long-term operation in harsh climates, such as in northern Europe [24,28]. Conductive power transfer with electric rails in the road is being tested by Volvo, Elways and other actors [29]. This solution is estimated to be less expensive, but it is not yet sufficiently tested in regard to safety and functionality, especially because the electric rail is located in the road surface, where it is exposed to weather influences and potential objects in the rail [30]. Conductive power supply from overhead lines is a more proven technology, due to its similarities to railway and trolleybus systems. Siemens and Scania are two main actors involved in the development of this concept and test tracks have been built and are in operation in Germany and Sweden. Some disadvantages are that passenger cars cannot use this ERS type, that masts and overhead lines have a visual impact, and that the overhead lines pose a risk for accidents.

This study focuses on conductive ERS with overhead lines, because (i) this technology is more mature [11,12]; (ii) information and data is available; and (iii) a large innovation procurement focusing on conductive solutions is currently taking place in Sweden with the aim to validate and test different ERS concepts [31].

\subsection{Strategic Planning towards Sustainability}

The transport system is highly complex and interconnected with other systems, such as, for example, the energy system. This makes it challenging to identify the actions and technologies that are strategic stepping stones on the way towards sustainability and, respectively, the ones that may later turn out to be costly dead ends. Therefore, there is a need for a framework that provides an understanding of the full scope of the sustainability challenge that includes a structure and inter-relational model to distinguish goals, tools, guidelines, and processes, and that offers an operational definition of sustainability that can be used as a basis for strategic thinking. Broman and Robèrt [32] have summarized two decades of research on the Framework for Strategic Sustainable Development (FSSD), which is designed to be such a framework that can be used to plan for sustainability in complex systems. The FSSD consists of five levels: system, success, strategy, action, and tools. Central to the FSSD is a backcasting approach: instead of asking what is likely to happen based on today's trends, backcasting starts out from the looked-for goal and then questions are asked as to what has to happen today and tomorrow in order to reach that goal, in this case a sustainable society. Apparently, a future vision of success plays a central role in this approach. A detailed vision of a sustainable future is, however, inflexible and difficult for many people to agree upon. On the other hand, a definition that is too general and vague is not useful as guidance for innovation. Therefore, the following basic sustainability principles (SPs) are used as a science-based definition of success [33]:

"In a sustainable society, nature is not subject to systematically increasing ...

1 ... concentrations of substances extracted from the Earth's crust;

2 ... concentrations of substances produced by society;

3 ... degradation by physical means; and, in that society ...

4 ...people are not subject to conditions that systematically undermine their capacity to meet their needs." 
These science-based, first-order principles essentially work as root causes for social and environmental issues. The social dimension of the SPs is currently under further development [34]. However, the above version of the principles was used as the new social SPs were not published and sufficiently tested at the time of the study. Rather than solving one current problem at a time and thereby risking running into costly dead ends as new unforeseen problems arise, the FSSD makes planning long term strategic by identifying and taking smart steps that lead towards compliance with the SPs [33].

\section{Methods}

This study used a combination of Strategic Life-Cycle Assessment (SLCA) and traditional Life-Cycle Assessment (LCA) with the aim to add a strategic planning perspective and to focus the LCA on the most important sustainability issues in the life-cycle (see Figure 1).

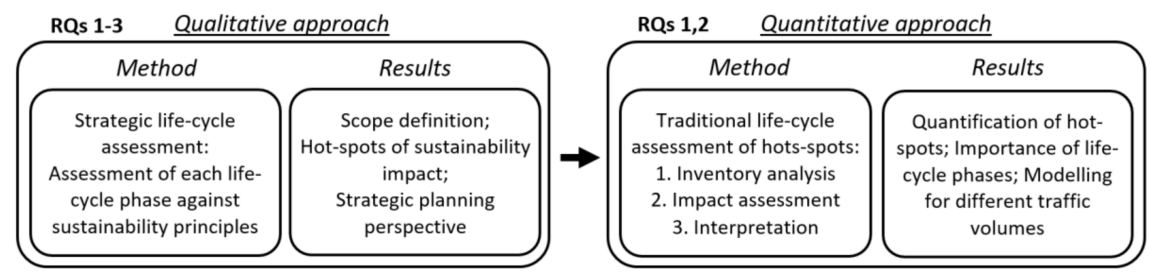

Figure 1. Schematic overview of the applied research methods and the results of each step.

\subsection{Strategic Life-Cycle Assessment}

Ny et al. [35] presented a method called Strategic Life-Cycle Assessment, which is used to identify a system's or product's violations against the SPs along the life-cycle. By doing so, "hot spots" of environmental and social impact are mapped in a qualitative way. These are further analyzed in a next step through quantitative LCA. That means that the results of the SLCA dictate the scope of the LCA, focusing it on the most important life-cycle stages and sustainability aspects. The SLCA in this study was conducted in multiple group sessions with several researchers and compared diesel-powered heavy trucks with corresponding trucks that are powered by ERS. In the beginning of the sessions, the team investigated the two systems and did a life-cycle mapping to get an overview of the most important processes, materials and energy flows. A template, cross referencing the life-cycle stages with the SPs was then used to systematically map SP violations throughout the life-cycles. Violations against SPs in each life-cycle are displayed in table format, in line with previous studies, combining text and a color scheme, ranging from 'neutral' over 'slightly negative' to 'negative', to indicate the magnitude of the violations [1,4]. In addition, one table describes how the systems would need to look like in order to fit into a sustainable future, or in other words, to comply with the SPs. A comparison between the "as is" and "to be" tables can give insight into whether it is realistically possible to achieve sustainability with these solutions. The most severe violations, that is, hot spots, were verified and partially quantified through LCA.

\subsection{Life-Cycle Assessment}

The LCA in this study followed the process of the ISO standard 14040 [36] but its scope was guided by the results of the SLCA as described above. The purpose was not to do a detailed and complete inventory and assessment of the systems. LCA was only used to quantify the most important environmental impacts of overhead line ERS powered trucks as compared to diesel trucks to be able to make a strategic assessment in line with the research questions.

The LCA software tool SimaPro 8.2 with the Ecoinvent 3.2 database [37] was used to model and compare the life-cycles. Model and results were verified by an independent LCA consultancy (Miljögiraff KB). The process started with a life-cycle inventory (LCI), in which inflows (e.g., raw materials and energy) and outflows (e.g., emissions) were mapped for all activities in the included life-cycle phases. Also, assumptions for the model were derived based on existing literature, statistics, 
etc., which is further explained in Section 4.2. The life-cycle impacts of ERS- and diesel-powered truck transport were compared per transported ton kilometer $(\mathrm{tkm})$. The latter thereby represents the functional unit of the study. Next, a life-cycle impact assessment (LCIA) was performed, following the steps of the ISO 14040 standard, to analyze the impact of the components and activities and their related in- and outflows. This phase started with the selection of impact categories. For this study, ReCiPe (H) midpoint and endpoint [38] were used as impact assessment methods, because they link all basic principles for socio-ecological sustainability with LCA, as described by Borén and $\mathrm{Ny}$ [4]. According to their work, systematic increase of substances in nature as described by SP1-2 can be linked to effect indicators in the following way: (i) combustion of fossil fuels leads to increasing concentration of $\mathrm{CO}_{2}$ in the atmosphere, which links to 'Climate Change' and 'Fossil Depletion'; (ii) usage of metals like copper, lead, nickel et cetera contribute to 'Metal Depletion' as long as they are not kept in closed loop systems; (iii) emissions of nitrogen oxides (NOx) from combustion of air and fuels link to 'Acidification', 'Eutrophication', 'Particulate Matter' and 'Photochemical oxidants'; and (iv) toxic and persistent chemicals such as dioxins and persistent organic pollutants contribute to 'Ecotoxicity' and 'Human Toxicity' categories. Systematic degradation of nature by physical means, SP3, for example, by open pit mining and landfills, links to the 'Land Use' categories. SP4, which defines social sustainability, is violated through negative health impacts from, for example, air pollution or radiation and is therefore linked to the categories 'Human Toxicity' and 'Ionizing Radiation'. Furthermore, the dissipate use of scarce resources, including fossil fuels and metals like copper, are a SP4 issue. Based on the ReCiPe method, LCI results were classified, meaning that all flows were assigned to one or multiple impact categories. In the following step, characterization, category indicator results were calculated with the help of characterization factors. To assess the magnitude of impacts and the relative importance of different impact categories, results were normalized by relating them to the yearly impact of an average citizen. Weighting, which is an optional step according to the ISO 14040 standard, was not performed in this study, as it is purely subjective. After the LCIA, the results were interpreted in relation to the research questions.

\section{Results}

\subsection{Strategic Life-Cycle Assessment of ERS and Diesel Truck Transport}

The SLCA mapped violations against SPs for truck transport on ERS- and diesel-powered trucks. The results are presented in one section for each SP in table format and the main impacts are discussed in text. Finally, a vision and requirement of a sustainable system is described as a definition of success for the specific case.

\subsubsection{Assessment against Sustainability Principle 1}

The biosphere and the lithosphere have always been connected to each other: substances from the lithosphere have entered the biosphere through, for example, volcanic eruptions. At the same time, substances from the biosphere have become part of the lithosphere as in the case of fossil fuels. Besides these natural flows, humans have since 200 years or so ago started to influence these flows to a considerable degree. However, this influence has almost entirely been in the form of an increased flow from the lithosphere to the biosphere. Consequences of such an increase and imbalance can have very negative implications both for humans and other living organisms: substances such as lead and cadmium, that normally only occur in very low concentrations in nature, can become a major health and ecosystem threat when their concentration increases systematically in nature as a result of, for example, leakage from mining. Even the increase of carbon dioxide in the atmosphere and its effects on global warming and ocean acidity are an example of a violation of SP1, as coal from the lithosphere is added to the biosphere much faster than it is removed from it [33].

When the case of ERS is assessed against SP1, Table 1, a considerable use of raw materials is identified, especially copper and steel, for catenaries, electric facilities, road barriers, catenary masts, 
etc. The extraction of these materials, as well as the production, cause spreading of heavy metals and other substances, which leads to increasing concentrations in the biosphere. In the use phase, SP1 is violated because of diffuse copper emissions from catenary friction and emissions from energy production, depending on the electricity mix. For the diesel system, production and combustion of the fuel clearly violates SP1. Common for both systems are diffuse emissions from, for example, road, tire, and break wear.

Table 1. Sustainability Principle 1 (SP1) strategic life-cycle assessment comparing Electric Road Systems (ERS) and diesel-powered freight transport.

\begin{tabular}{lll}
\hline Life-Cycle Phase & \multicolumn{1}{c}{ SP1 Effects of ERS-Powered Trucks } & \multicolumn{1}{c}{ SP1 Effects of Diesel-Powered Trucks } \\
\hline \multirow{2}{*}{ Extraction } & $\begin{array}{l}\text { Heavy metals in components and processes. } \\
\text { Emissions from fossil fuel usage. }\end{array}$ & $\begin{array}{l}\text { Heavy metals in components and processes. } \\
\text { Emissions from fossil fuel usage. Oil } \\
\text { leakages, gas flaring. }\end{array}$ \\
\hline \multirow{2}{*}{ Production } & $\begin{array}{l}\text { Heavy metals in components and } \\
\text { production. Emissions from fossil fuel } \\
\text { usage. }\end{array}$ & $\begin{array}{l}\text { Heavy metals in components and } \\
\text { production. Emissions from fossil fuel } \\
\text { usage. }\end{array}$ \\
\hline Distribution & $\begin{array}{l}\text { Emissions from truck transports of } \\
\text { infrastructure systems, vehicles. }\end{array}$ & $\begin{array}{l}\text { Emissions from truck transports of } \\
\text { infrastructure systems, vehicles and fuel. }\end{array}$ \\
\hline \multirow{2}{*}{ Use } & $\begin{array}{l}\text { Copper emissions from catenary wire } \\
\text { friction. Heavy metals in maintenance. } \\
\text { Emissions from maintenance transport. }\end{array}$ & $\begin{array}{l}\text { Combustion emissions. Heavy metals and } \\
\text { fossil oil in maintenance. Emissions from } \\
\text { maintenance transport. }\end{array}$ \\
\hline \multirow{3}{*}{ Waste } & $\begin{array}{l}\text { Incomplete recycling of heavy metals and } \\
\text { other materials related to SP1. Some cables } \\
\text { and other components may be left in } \\
\text { the ground and leak heavy metals. } \\
\text { Emissions and leakages from recycling } \\
\text { processes and landfills. }\end{array}$ & $\begin{array}{l}\text { Incomplete recycling of heavy metals and } \\
\text { other materials related to SP1. Emissions } \\
\text { and leakages from recycling processes and } \\
\text { landfills. }\end{array}$ \\
\hline
\end{tabular}

Red: negative sustainability impact; yellow: slightly negative sustainability impact.

\subsubsection{Assessment against Sustainability Principle 2}

Emissions of persistent chemicals or $\mathrm{NO}_{X}$ are examples of SP2 violations. When ERS is assessed against SP2, Table 2, it is found that the infrastructure includes many electric facilities and cables, which can contain plastic insulation with persistent additives. These chemicals can leak and accumulate in nature, for example when cables are left in the ground even after the ERS' end-of-life. Another main SP2 violation occurs when burning fossil fuels, both in vehicles and for electricity production (depending on the electricity mix), which causes $\mathrm{NO}_{\mathrm{X}}$ emissions, contributing to eutrophication and acidification.

Table 2. SP2 strategic life-cycle assessment comparing ERS- and diesel-powered freight transport.

\begin{tabular}{|c|c|c|}
\hline Life-Cycle Phase & SP2 Effects of ERS-Powered Trucks & SP2 Effects of Diesel-Powered Trucks \\
\hline Extraction & $\mathrm{NO}_{x}$ emissions from combustion. & $\mathrm{NO}_{X}$ emissions from combustion. \\
\hline Production & $\begin{array}{l}\text { NOx emissions from combustion. POP and } \\
\text { Dioxin emissions. }\end{array}$ & $\begin{array}{l}\text { NOx emissions from combustion. POP } \\
\text { and Dioxin emissions. }\end{array}$ \\
\hline Distribution & $\begin{array}{l}\mathrm{NO}_{X} \text { emissions from truck transports of } \\
\text { infrastructure systems and vehicles. }\end{array}$ & $\begin{array}{l}\mathrm{NO}_{\mathrm{X}} \text { emissions from truck transports of } \\
\text { infrastructure systems and vehicles. }\end{array}$ \\
\hline Use & $\begin{array}{l}\mathrm{NO} \text { emissions from truck transports of } \\
\text { infrastructure systems and maintenance } \\
\text { vehicles. Leakage of persistent chemicals } \\
\text { from electric components. }\end{array}$ & $\begin{array}{l}\mathrm{NO}_{X} \text { emissions from truck transports of } \\
\text { infrastructure systems and maintenance } \\
\text { vehicles. NOX emissions from } \\
\text { the vehicle's engine. Leakage of } \\
\text { persistent chemicals from electric } \\
\text { components. }\end{array}$ \\
\hline Waste & $\begin{array}{l}\text { Incomplete recycling of compounds related } \\
\text { to SP2. Emissions and leakages from } \\
\text { recycling processes and landfills. }\end{array}$ & $\begin{array}{l}\text { Incomplete recycling of compounds } \\
\text { related to SP2. Emissions and leakages } \\
\text { from recycling processes and landfills. }\end{array}$ \\
\hline
\end{tabular}

Red: negative sustainability impact; yellow: slightly negative sustainability impact. 


\subsubsection{Assessment against Sustainability Principle 3}

According to SP3, nature must not be degraded by physical means. In contrast to SP1-2, SP3 is not about systematically increasing concentrations but about destruction of nature through land use or mismanagement of ecosystems. Open pit mining and oil extraction are the most relevant violations of SP3 in the ERS case, Table 3, because they occupy and degrade large surface areas through leakages of hazardous substances, risking destruction of soil and water resources. Such areas are often not usable, neither by humans, animals nor plants. SP3 is here also violated by building infrastructure for electricity and by fuel production and distribution, because they hinder the use of productive surfaces and might contribute to deforestation and fragmentation. Finally, as some components are not recycled, they contribute to increasing landfill space.

Table 3. SP3 strategic life-cycle assessment comparing ERS- and diesel-powered freight transport.

\begin{tabular}{lll}
\hline Life-Cycle Phase & SP3 Effects of ERS-Powered Trucks & SP3 Effects of Diesel-Powered Trucks \\
\hline Extraction & Open pit mining of metals. & $\begin{array}{l}\text { Open pit mining of metals and other } \\
\text { resources. Oil extraction. }\end{array}$ \\
\hline Production & & Contamination at refineries. \\
\hline Distribution & Land use for roads and power grids. & Land use for roads and pipelines. \\
\hline Use & Land use for roads. & Land use for roads. \\
\hline Waste & Non-recycled materials to landfills. & Non-recycled materials to landfills. \\
\hline \multicolumn{2}{c}{ Red: negative sustainability impact; yellow: slightly negative sustainability impact; blue: neutral. }
\end{tabular}

\subsubsection{Assessment against Sustainability Principle 4}

While the first three principles focus on ecological sustainability, SP4 is about meeting human needs, which also is a requirement for a sustainable future. The assessment against SP4, Table 4, emphasizes the mining and fossil fuel industries that are plagued by conflicts, whose effects prevent people from meeting their needs, for example because they get wounded or are forced to flee their homes. These industries also cause ecosystem degradation by physical and chemical means, which undermines not only people's health but also their possibilities to make a living with agriculture, fishing or livestock farming. The same is true for the production phase and metal recovery in some countries that expose people and nature to hazardous emissions [39]. Another violation of SP4 may occur when scarce resources are extracted and used in a way that limits their availability for future generations. This is the case for fossil fuels and metals like copper [40,41] and platinum [42].

Table 4. SP4 strategic life-cycle assessment comparing ERS- and diesel-powered freight transport.

\begin{tabular}{lll}
\hline Life-Cycle Phase & \multicolumn{1}{c}{ SP4 effects of ERS-Powered Trucks } & $\begin{array}{l}\text { SP4 Effects of Diesel-Powered Trucks } \\
\text { Extraction }\end{array}$ \\
\hline $\begin{array}{l}\text { Use of scarce resources such as copper. } \\
\text { Open pit mining causes negative health } \\
\text { effects and forces people to move. }\end{array}$ & $\begin{array}{l}\text { Use of scarce resources such as } \\
\text { platinum. Open pit mining causes } \\
\text { negative health effects and forces people } \\
\text { to move. }\end{array}$ \\
\hline Production & $\begin{array}{l}\text { Negative health effects from emissions } \\
\text { related to fossil fuel use and component } \\
\text { production. Harmful job conditions at some } \\
\text { places. }\end{array}$ & $\begin{array}{l}\text { Negative health effects from emissions } \\
\text { related to fossil fuel use and component } \\
\text { production. Harmful job conditions at } \\
\text { some places. }\end{array}$ \\
\hline Distribution & Health effects from transport emissions. & Health effects from transport emissions. \\
\hline Use & $\begin{array}{l}\text { Health risks due to high voltage and } \\
\text { overhead line accidents. }\end{array}$ & $\begin{array}{l}\text { Negative health effects from emissions } \\
\text { related to fossil fuel use. }\end{array}$ \\
\hline Waste & $\begin{array}{l}\text { Harmful emissions and working conditions } \\
\text { in some countries. }\end{array}$ & $\begin{array}{l}\text { Harmful emissions and working } \\
\text { conditions in some countries. }\end{array}$ \\
\hline
\end{tabular}

Red: negative sustainability impact; yellow: slightly negative sustainability impact.

The introduction of ERS might also create positive effects like new jobs in all life-cycle phases. On the other hand, they might just replace jobs from other infrastructure systems, which leaves the net 
effect on job creation uncertain. However, an increased demand for renewable energy and a transition of the energy sector is expected to lead to a net increase of jobs in Europe [3,43,44].

\subsubsection{Requirements for Sustainable Freight Transport Systems}

When investments in new infrastructure are planned with the goal to make transportation more sustainable, it is important to investigate what would be required for the systems to be fully sustainable. Otherwise there is a risk of sub-optimization and a risk that society once again gets locked into an unsustainable system for half a century or longer. Especially in the case of ERS, which have a long life-time, one has to consider the question of whether the concept will provide a stepping stone towards a sustainable society and compliance with the SPs. The results of the SLCA revealed that the most severe sustainability challenges for ERS are (i) the extensive use of raw materials, including scarce metals like copper; (ii) diffuse emissions in the use phase, especially copper from catenary friction; (iii) environmental impact of the electricity used in the system; and (iv) use of fossil fuels for processes and activities throughout the life-cycle.

Table 5 shows the most important aspects of how the life-cycle would need to look like in order to not violate any SP. Of central importance for reaching compliance with the SPs are the strict application of best available technology (BAT) and precautionary and substitution principles in all life-cycle phases. As Robèrt et al. [33] emphasize, SP1 does not forbid all use of metals. Rather, they should be handled in closed loops so that the concentration in nature does not increase and the available resources are not depleted. However, it would be more favorable to design a system that is completely independent of rare or toxic materials and substances. Fossil oil should be avoided completely. Good, safe and just working conditions have to be guaranteed in all life-cycle phases. When these requirements are met, a sustainable transport solution can be a valuable, long-term satisfier of human transportation needs.

Table 5. Life-cycle requirements on ERS, viewed through the lens of the four sustainability principles.

\begin{tabular}{ll}
\hline Life-Cycle Phase & \multicolumn{1}{c}{ Requirements for Sustainable ERS } \\
\hline Extraction & $\begin{array}{l}\text { Very limited extraction of new resources. Extraction with best available } \\
\text { technology (BAT). Complete restauration of the site after operation. Respecting } \\
\text { indigenous people's rights. }\end{array}$ \\
\hline Production & $\begin{array}{l}\text { Strict application of BAT, precautionary and substitution principle. Rare } \\
\text { substances with high accumulation potential are kept in closed loops. }\end{array}$ \\
\hline Distribution & Only using sustainable modes of transport powered by renewable energy. \\
\hline Use & $\begin{array}{l}\text { Ensuring a safe, comfortable and effective satisfaction of people's need for } \\
\text { transportation *. Only renewable energy input and no emissions of critical } \\
\text { substances from use and maintenance. }\end{array}$ \\
\hline Waste & $\begin{array}{l}\text { Optimized for following EU's waste hierarchy [45]: prevention, reuse, recycle, } \\
\text { recovery; except there should be no need for landfilling. Circular material flow. }\end{array}$ \\
\hline & *A contribution to sustainable development. blue: neutral.
\end{tabular}

\subsection{Life-Cycle Assessment of ERS and Current Fossil-Powered Truck Transport}

As a result of the SLCA, the main hot spots identified were raw material extraction, production and use phases, which therefore were selected for quantification with LCA. Included processes and components are: (i) raw material extraction for roads, lorries, diesel, and road electrification; (ii) processes for turning the raw material into products; (iii) combustion of diesel, emissions from electricity generation, catenary friction, road, break, and tire wear emissions, and lorry maintenance. The other life-cycle phases were excluded from the LCA. The inventory analysis of the infrastructure utilized data from $1000 \mathrm{~V}$ railway systems, which use very similar components to overhead line ERS. This data was further adjusted with the help of a railway and ERS expert. For the components where there was no suitable data in Ecoinvent, simplified components were modelled (see Table 6). 
Table 6. Simplified modelling of ERS components, using Ecoinvent data.

\begin{tabular}{|c|c|c|c|}
\hline Component & Material Use per km & $\begin{array}{l}\text { Technical Life } \\
\text { Time, Years }\end{array}$ & Reference \\
\hline Overhead lines (double) & Copper: $4800 \mathrm{~kg}$ & 40 & $\begin{array}{l}\text { Swedish Transport Administration } \\
\text { [46], Stripple and Uppenberg [47] }\end{array}$ \\
\hline Catenary masts & $\begin{array}{l}\text { Steel: } 7752 \mathrm{~kg} \\
\text { PE: } 122 \mathrm{~kg} \\
\text { Fiberglass: } 152 \mathrm{~kg}\end{array}$ & 50 & $\begin{array}{l}\text { Swedish Transport Administration } \\
\text { [46], Stripple and Uppenberg [47] }\end{array}$ \\
\hline Semi-rigid roadside barriers & $\begin{array}{l}\text { Concrete: } 5500 \mathrm{~kg} \\
\text { Steel: } 16,000 \mathrm{~kg}\end{array}$ & 20 & $\begin{array}{l}\text { Swedish Transport Administration } \\
\text { [46], Stripple and Uppenberg [47] }\end{array}$ \\
\hline $\begin{array}{l}\text { Electrical equipment, protective } \\
\text { relay, fuses }\end{array}$ & Steel: $57 \mathrm{~kg}$ & 40 & Uppenberg [48] \\
\hline Cables, AXQJ 1 kV 3×70/21 & $\begin{array}{l}\text { Aluminium: } 363 \mathrm{~kg} \\
\text { Copper: } 121 \mathrm{~kg} \\
\text { PE: } 216 \mathrm{~kg}\end{array}$ & 40 & Uppenberg [48] \\
\hline Distribution sheds & $\begin{array}{l}\text { Steel, low-alloyed: } \\
145 \mathrm{~kg}\end{array}$ & 50 & Uppenberg [48] \\
\hline Transformer 1/0,4 kV, $100 \mathrm{kVA}$ & $\begin{array}{l}\text { Steel: } 3 \mathrm{~kg} \\
\text { Copper: } 1 \mathrm{~kg}\end{array}$ & 40 & Uppenberg [48] \\
\hline Transformer 1/0,4 kV, $50 \mathrm{kVA}$ & $\begin{array}{l}\text { Steel: } 89 \mathrm{~kg} \\
\text { Copper: } 38 \mathrm{~kg}\end{array}$ & 40 & Uppenberg [48] \\
\hline Transformer 1/0,4 kV, $30 \mathrm{kVA}$ & $\begin{array}{l}\text { Steel: } 3 \mathrm{~kg} \\
\text { Copper: } 1 \mathrm{~kg}\end{array}$ & 40 & Uppenberg [48] \\
\hline Transformer 1/0,4 kV, $16 \mathrm{kVA}$ & $\begin{array}{l}\text { Steel: } 3 \mathrm{~kg} \\
\text { Copper: } 1 \mathrm{~kg}\end{array}$ & 40 & Uppenberg [48] \\
\hline Transformer $1 / 0,4 \mathrm{kV}, 5 \mathrm{kVA}$ & $\begin{array}{l}\text { Steel: } 3 \mathrm{~kg} \\
\text { Copper: } 1 \mathrm{~kg}\end{array}$ & 40 & Uppenberg [48] \\
\hline
\end{tabular}

Market processes and system model "allocation, cut-off by classification" were used for all materials and processes [49]. Europe was chosen as the geographical reference point. The value chain can, however, include materials and processes from other parts of the world. Four scenarios for electricity generation were applied, all based on Ecoinvent data: European mix, Nordic mix, wind-generated electricity, and a worst-case scenario that assumed coal-generated marginal electricity. The type of electricity for vehicle propulsion in the use phase is the only difference between the scenarios, thereby showing the sensitivity of the model for this key factor. Truck traffic volume was initially set to 1000 vehicles per direction and day, which corresponds to a major Swedish highway [30]. Trucks had a gross vehicle weight of 16-32 ton, with an average load factor of 5.79 ton [50]. Diesel trucks met Euro 6 emission limits. Diesel consumption was $0.037 \mathrm{~L} / \mathrm{tkm}$, which corresponds to $0.21 \mathrm{~L} / \mathrm{km}$ (Ecoinvent 3.2 database). Electricity consumption was set to $0.17 \mathrm{kWh} / \mathrm{tkm}$, which corresponds to the same amount of energy consumption as the diesel truck when calculating with diesel engine efficiency of $42 \%$, electric engine efficiency of $95 \%$, and electricity losses in the ERS of five percent. Catenary friction was estimated as $10 \mathrm{~kg}$ of copper per $\mathrm{km}$ and year, which is the same amount as for railway systems [51]. Without full scale tests it is, however, yet uncertain whether this data is fully valid for ERS due to differences in traffic intensity, speed, and movement of the pantograph-shaped pick-up.

Comparing characterization results of ERS- and diesel-powered trucks, Figure 2, revealed: (i) wind-powered ERS have lower environmental impact than the diesel system in 11 out of 18 impact categories; (ii) ERS powered by European electricity mix or marginal electricity have higher environmental impact in 12 and 13 out of 18 categories respectively, as compared to the current diesel system. That number is 10 for the Nordic electricity mix scenario; (iii) there are substantial differences in GHG emissions: ERS that use coal-based marginal electricity cause the highest emissions $(229 \mathrm{~g} / \mathrm{tkm})$, followed by diesel $(165 \mathrm{~g} / \mathrm{tkm})$, EU mix electricity $(117 \mathrm{~g} / \mathrm{tkm})$, Nordic mix $(41 \mathrm{~g} / \mathrm{tkm})$ and wind-generated electricity $(31 \mathrm{~g} / \mathrm{tkm})$; and (iv) a closer look at ERS infrastructure reveals that most environmental impacts are tied to the three components of copper catenaries, catenary masts and road barriers. Other parts, such as converters or cables, play a minor role. 


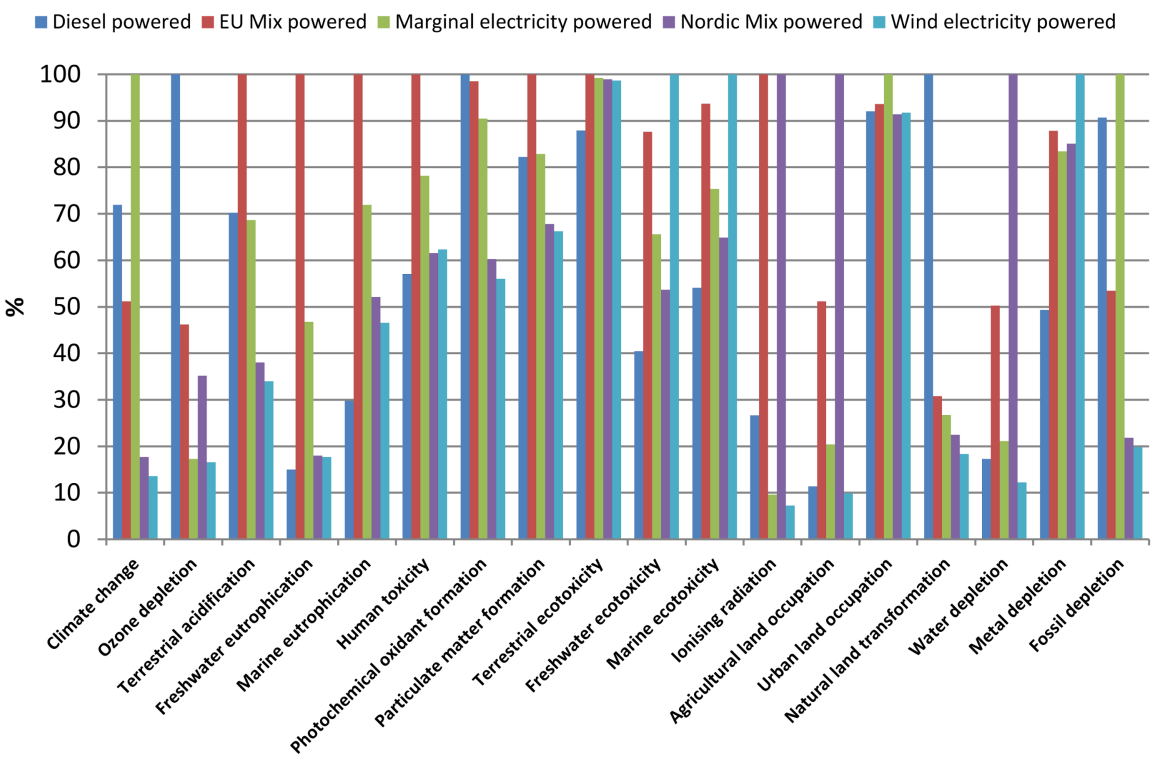

Figure 2. Characterization results with ReCiPe midpoint showing life-cycle environmental impact for diesel-powered freight transport and ERS. Whether ERS have lower life-cycle environmental impact is strongly dependent on how electricity is produced.

Normalization of the results shows that freshwater eutrophication, human toxicity, eco-toxicity and natural land transformation are the most relevant impact categories for the investigated systems. ERS, no matter how electricity is generated, have higher impact in the toxicity categories, which is largely due to the extensive use of copper and emissions from catenary friction. The fossil-powered system has a much higher impact on natural land transformation, mainly due to petroleum production.

A closer look at the role of different life-cycle phases for the climate change category, Figure 3, reveals that most emissions occur in the use phase if trucks are powered by diesel, marginal electricity or EU mix electricity. If electricity is produced in a less carbon intensive way, as is the case with Nordic mix and wind-power, extraction to distribution (E-D) phases constitute the main source of $\mathrm{CO}_{2}$ equivalent $\left(\mathrm{CO}_{2} \mathrm{e}\right)$ emissions. It is, however, not the ERS infrastructure that causes high emissions in E-D phases. Instead, road and lorry production cause about $20 \mathrm{~g} \mathrm{CO}_{2} \mathrm{e}$ emissions per $\mathrm{tkm}$, which can be compared with $1.5 \mathrm{~g} / \mathrm{tkm}$ for electrification of the road with ERS.

The amount of $\mathrm{tkm}$ transported on ERS is a central parameter: the more goods that are transported on an ERS, the less is the share of building the infrastructure, E-D phases, for each $\mathrm{tkm}$. The number of tkm is in turn dependent on the number of trucks and their average load factor. In order to evaluate if electrification of a specific road is favorable from a sustainability perspective, it is necessary to adjust the assumptions of the LCA model. Figure 4 clarifies the dependence of life-cycle environmental impact and the number of $\mathrm{tkm}$ transported on ERS. It shows the environmental break-even times for the different scenarios, that is, the time until the environmental impact of the road electrification is compensated by lower impact in the use phase. ReCiPe endpoint was used to get one accumulated, comparable number for environmental impacts. The marginal electricity scenario is not displayed because it has higher life-cycle environmental impact per $\mathrm{tkm}$ than the diesel system, hence there is no break-even. 


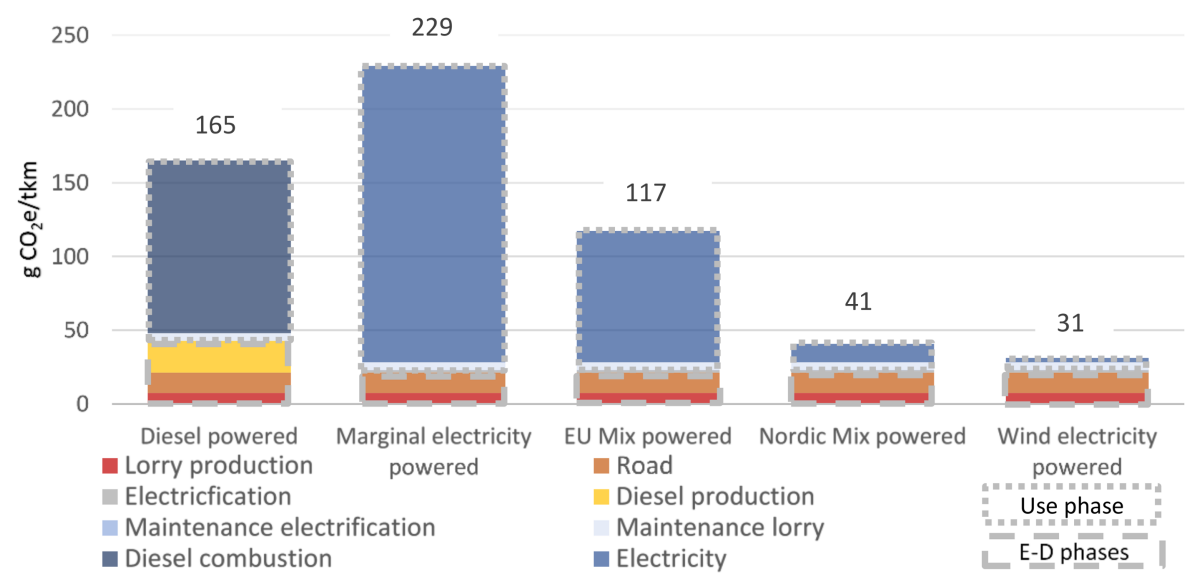

Figure 3. Contribution of extraction to distribution and use life-cycle stages to total climate change impact of diesel- and ERS-powered freight transport.

Generally, break-even times are short if Nordic mix or wind-power generated electricity are used: assuming 1000 trucks per day, break-even is only three to four years and with 500 trucks per day that time is below 10 years. The situation is different, though, if EU mix electricity is assumed: a minimum of about 700 trucks per day is required to achieve a break-even time of 10 years, and with 1000 heavy vehicles per day, that time is seven to eight years. A break-even time shorter than five years is only possible on roads with high traffic flow of more than 1400 trucks per direction and day. From a purely GHG emission perspective, break-even times are considerably (about 70\%) shorter when assuming the same amount of freight transport per day. Climate change is, however, only one of many impacts that have to be considered.

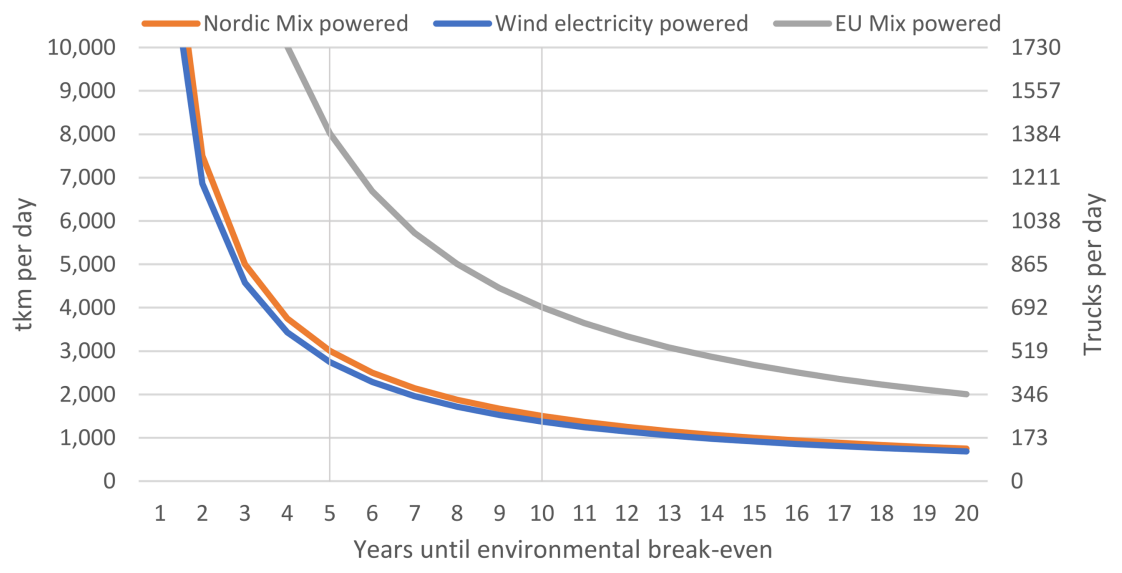

Figure 4. Environmental break-even times for ERS in relation to electric freight traffic amounts, that is, the time it takes until impact (ReCiPe endpoint) from building ERS is offset by lower emissions in the use phase, as compared to diesel-powered freight transport.

\section{Concluding Discussion}

\subsection{What Is the Sustainability Impact of ERS in Comparison to the Current Fossil-Powered System?}

The SLCA showed that both ERS and diesel freight transport have some severe sustainability impacts and violations against the SPs, especially in raw material extraction, production and use phases. For ERS, these are mostly due to usage of large amounts of copper and other raw materials, as well as impacts from electricity production and diffuse emissions in the use phase. For diesel transport, the value chain of oil and fuel combustion are main causes of the violations. Possibilities 
to reduce these SP violations were identified and are mostly about the application of 'best available technology', 'substitution' and 'precautionary' principles throughout the life-cycle as well as closing the loop of material flows and using sustainably harvested, renewable energy.

The more detailed LCA showed that GHG emissions can be decreased significantly as long as electricity generation is not coal-based. GHG payback times are five years for roads with more than 400 lorries per day and below two years if there are at least 1000 lorries per day. However, based on normalization results, the most relevant environmental impact categories are eco-toxicity, human toxicity, eutrophication and, especially for the diesel system, natural land transformation. These findings underline the importance of widening the view on sustainability beyond climate change and GHG emissions. In total, endpoint results show that transport on coal electricity powered ERS causes higher environmental impact than driving on diesel, while the impact is lower if EU mix, Nordic mix or wind-generated electricity is used. This emphasizes the fact that the sustainability performance of ERS is highly dependent on how electricity for the use phase is produced. Therefore, a transition of the transport sector to be powered by electricity has to be simultaneously accompanied by a transition of the energy system to $100 \%$ flow-based, renewable energy. As intrinsic to LCA, results are dependent on model assumptions, especially concerning the share of electrified roads, traffic volume and load factor, which is related to average lorry weight. Therefore, these parameters have to be adjusted in order to evaluate the environmental impact for specific cases.

\subsection{What Is the Relative Importance of Different Life-Cycle Phases?}

Through SLCA, the raw material extraction, production and use phases were identified as hot spots of sustainability impact. In general, most environmental impacts occur in the use phase, both for diesel and ERS systems, even if wind-generated electricity is used. This dominance of the use phase is a common result of LCAs for transport systems and many other products [1,4,47]. However, if the electricity for ERS is produced in a sustainable way, the impact of the infrastructure itself becomes more prominent, which was also apparent in Figure 3. The SLCA showed that ERS infrastructure still has major sustainability challenges, especially due to copper and steel use for catenaries, masts and road barriers. As these components constitute relatively pure fractions, there might be good possibilities for a high degree of material recycling. In this regard, diffuse emissions in the use phase, like copper from catenary friction, are more difficult to prevent and control. It is therefore important to include infrastructure in LCAs of transport systems. Sustainability challenges of the current diesel system are mainly characterized by the petroleum value chain, which includes extensive land use, and diesel combustion with a variety of emissions.

5.3. Is the Introduction of ERS a Strategic Stepping Stone on the Way towards Sustainable Transport and What Role Could They Play in That Transition?

\subsubsection{Lock-In and Threshold Effects}

The life-cycle inventory revealed that many ERS components have a long life-time. Even though that has some sustainability advantages, it also means that ERS as a transport solution has a long life-time. That fact in combination with high initial investment costs means that there might be a strong lock-in effect: once built and invested in, ERS would have to be used for a long time, presumably many decades, in order to be environmentally and economically viable, depending on how the infrastructure is financed. Thus, ERS is not a flexible solution as compared to some other infrastructure solutions, such as fast charging networks that relatively easily and quickly can be expanded, decreased or even phased out. On the other hand, this study indicated that environmental pay-off times are relatively short, if electricity is produced in a sustainable way and the freight transport volume is sufficiently high. A challenge that ERS share with several other systems, for example fast charging, battery swapping, and fuel cell stations, is the threshold effect: as long as there is no substantial network of infrastructure, it is not attractive for haulage contractors to invest in more expensive vehicles that are adjusted for 
using ERS. Today, it is largely unclear how strong such a threshold effect is for ERS. It depends largely on the share of electrified roads, business models, and to what degree a specific lorry travels on a fixed or flexible and constantly changing route.

\subsubsection{Stepping Stones towards Sustainability}

As a comparison of the future requirements for a sustainable infrastructure (Table 5) and the assessment of today's state (Tables 1-4) showed, there is a considerable discrepancy between 'as is' and 'to be'. That in itself is not a reason to dissuade from investments in ERS, as all alternatives, for example fuel cell or battery-powered systems, today have some violations against the SPs [4]. In addition, some violations might be possible to solve through smart design and technology development. However, the most important question to ask is which infrastructure system is the smartest "stepping stone" [32] on the way to a sustainable future. This means that it is not only important to find today's most sustainable solution, but also to find the technology platform with the largest potential to lead us on the right track and closer to reach full socio-ecological sustainability over time. From this perspective, ERS could prove to be a valuable part of the puzzle, mostly because they drastically decrease the need for large batteries, which results in lower vehicle cost and sustainability impact. Thereby, ERS could catalyze electrification and the transition towards sustainable freight transport. ERS are, however, at an early stage of development [16]. In the short term, the application of ERS for closed systems, for example transport of ore between a mine and a production facility or a harbor, is important for testing and further development of the concept. Closed systems have much lower complexity as fewer stakeholders are involved, the need for standardization is limited, and both economic cost-benefit and wider sustainability assessments are considerably simpler [15]. The application in closed systems would, however, only solve a small fraction of the freight transports' sustainability challenges and the total GHG reduction potential is rather low. Still, it is a valuable way to gather experience and knowledge on ERS before heavily investing in road electrification to overcome the threshold effect for ordinary freight transport.

\subsection{Recommendations and Future Research}

Based on the findings of this study, the following recommendations are made to accelerate the transition of road freight transport towards sustainability. Firstly, the ERS concept should be further explored and developed, specifically regarding business models for open systems and the dynamics between the amount of electrified road and the rationale for actors to invest in ERS-compatible vehicles. Secondly, test applications and demonstrators play a key role in the early phases of technology development but are in many cases dependent on public funding. Incentives for public funding could be strengthened by detailing the societal benefits of ERS, including savings in relation to the externalities of the current system. Thirdly, political will and a clear strategy are required to reduce uncertainty for private companies, making it more attractive to invest in ERS. Finally, and most importantly, strategic leadership is needed to guide the development of freight transport towards sustainability, without sub-optimizations in the transport sector and solutions in the transport sector that block sustainable solutions in other sectors. For this purpose, Robèrt et al. [52] and Borén et al. [53] presented an FSSD-based process model for cross-sector and cross-disciplinary cooperation, ensuring cohesive creativity across sectors and groups of experts as well as stakeholders. In the end, ERS also need to be compared with alternative technologies like battery electric trucks and fuel cell trucks. It is likely that a combination of technologies will exist in the future to fit different needs and contexts, even if some technology might dominate. Exactly which role ERS will play is yet to be seen and also dependent on progress with other technologies. For instance, the possibilities for a sustainable scale-up of battery electric trucks is largely dependent on breakthroughs in battery design. For fuel cell solutions, increased system efficiency and a substitution or limited use of platinum would be necessary. In any case, with the applying of a strategic perspective based on backcasting from a vision 
of full sustainability, policy and decision-makers can ensure that actions lead step-wise towards a sustainable society.

Acknowledgments: Sincere thanks to our colleague Sven Borén for valuable discussions on SLCA and LCA methodology and results. Also, Pär Lindman at the Swedish SimaPro dealer Miljögiraff KB contributed to the study by supporting and verifying the LCA model.

Author Contributions: Jesko Schulte collected the data, developed the LCA model, performed most of the analysis and led the writing process. Henrik Ny headed the research group, initiated the study, supported the life-cycle assessments, participated in the analysis, and revised the manuscript.

Conflicts of Interest: The authors declare no conflict of interest. The founding sponsors had no role in the design of the study; in the collection, analyses, or interpretation of data; in the writing of the manuscript, and in the decision to publish the results.

\section{References}

1. Nurhadi, L.; Borén, S.; Ny, H. Advancing from Efficiency to Sustainability in Swedish Medium-sized Cities: An Approach for Recommending Powertrains and Energy Carriers for Public Bus Transport Systems. Procedia Soc. Behav. Sci. 2014, 111, 586-595. [CrossRef]

2. European Commission. EU Transport in Figures: Statistical Pocketbook 2015; European Commission: Luxembourg, Luxembourg, 2015.

3. Teske, S.; Sawyer, S.; Schäfer, O.; Pregger, T.; Simon, S.; Naegler, T. Energy [R]evolution-A Sustainable World Energy Outlook 2015; Greenpeace International, Global Wind Energy Council, Solar Power Europe: Brussels, Belgium, 2015.

4. Borén, S.; Ny, H. A Strategic Sustainability and Life Cycle Analysis of Electric Vehicles in EU today and by 2050. In Proceedings of the 18th International Conference on Sustainable Urban Transport and Environment (ICSUTE), Madrid, Spain, 24-25 March 2016; Volume 10, pp. 256-264.

5. European Commission. A Strategy for Reducing Heavy Duty Vehicles' Fuel Consumption and $\mathrm{CO}_{2}$ Emissions; European Commission: Brussels, Belgium, 2014.

6. ICCT. European Vehicle Market Statistics—Pocketbook 2014; ICCT: Berlin, Germany, 2014.

7. Notter, D.A.; Gauch, M.; Widmer, R.; Wäger, P.; Stamp, A.; Zah, R.; Althaus, H.-J. Contribution of Li-ion batteries to the environmental impact of electric vehicles. Environ. Sci. Technol. 2010, 44, 6550-6556. [CrossRef] [PubMed]

8. Hawkins, T.R.; Singh, B.; Majeau-Bettez, G.; Strømman, A.H. Comparative Environmental Life Cycle Assessment of Conventional and Electric Vehicles. J. Ind. Ecol. 2013, 17, 53-64. [CrossRef]

9. Sverdrup, H.U.; Ragnarsdottir, K.V.; Koca, D. An assessment of metal supply sustainability as an input to policy: Security of supply extraction rates, stocks-in-use, recycling, and risk of scarcity. J. Clean. Prod. 2017, 140, 359-372. [CrossRef]

10. Kushnir, D.; Sandén, B.A. The time dimension and lithium resource constraints for electric vehicles. Resour. Policy 2012, 37, 93-103. [CrossRef]

11. Connolly, D. Economic viability of electric roads compared to oil and batteries for all forms of road transport. Energy Strateg. Rev. 2017, 18, 235-249. [CrossRef]

12. Tongur, S.; Engwall, M. The business model dilemma of technology shifts. Technovation 2014, 34, 525-535. [CrossRef]

13. Chen, F.; Taylor, N.; Kringos, N. Electrification of roads: Opportunities and challenges. Appl. Energy 2015, 150, 109-119. [CrossRef]

14. Lennartsson, M. Elektriska Vägar, Miljöanalys (Electric Roads, Environmental Analysis). Available online: http:/ / elvag.se/en/archive/2010-04-16/Elektriska-vagar-Miljoanalys.pdf (accessed on 7 July 2016).

15. Tongur, S.; Sundelin, H. The electric road system transition from a system to a system-of-systems. In Proceedings of the Asian Conference on Energy, Power and Transportation Electrification (ACEPT), Singapore, Singapore, 25-27 October 2016; pp. 1-8.

16. Sundelin, H.; Gustavsson, M.G.H.; Tongur, S. The maturity of electric road systems. In Proceedings of the International Conference on Electrical Systems for Aircraft, Railway, Ship Propulsion and Road Vehicles \& International Transportation Electrification Conference (ESARS-ITEC), Toulouse, France, 2-4 November 2016. 
17. Choi, S.Y.; Member, S.; Gu, B.W.; Member, S.; Jeong, S.Y.; Member, S.; Rim, C.T.; Member, S. Advances in Wireless Power Transfer Systems for Roadway-powered Electric Vehicles. IEEE J. Emerg. Sel. Top. Power Electron. 2015, 3, 18-36. [CrossRef]

18. Suh, N.P.; Cho, D.H.; Rim, C.T. Design of On-Line Electric Vehicle (OLEV). In Global Product Development; Springer: Berlin/Heidelberg, Germany, 2011; pp. 3-8.

19. Stamati, T.; Bauer, P. On-road charging of electric vehicles. In Proceedings of the 2013 IEEE Transportation Electrification Conference and Expo (ITEC), Detroit, MI, USA, 16-19 June 2013; pp. 1-8.

20. Sallan, J.; Villa, J.L.; Llombart, A.; Sanz, J.F. Optimal Design of ICPT Systems Applied to Electric Vehicle Battery Charge. IEEE Trans. Ind. Electron. 2009, 56, 2140-2149. [CrossRef]

21. Covic, G.A.; Boys, J.T. Modern Trends in Inductive Power Transfer for Transportation Applications. IEEE J. Emerg. Sel. Top. Power Electron. 2013, 1, 28-41. [CrossRef]

22. Gill, J.S.; Bhavsar, P.; Chowdhury, M.; Johnson, J.; Taiber, J.; Fries, R. Infrastructure cost issues related to inductively coupled power transfer for electric vehicles. Procedia Comput. Sci. 2014, 32, 545-552. [CrossRef]

23. FABRIC Test Sites. Available online: http://www.fabric-project.eu/index.php?option=com_k2\&view= itemlist\&layout=category\&task=category\&id=24\&Itemid=214 (accessed on 13 February 2018).

24. Viktoria Swedish ICT. Slide-in Electric Road System-Inductive Project Report; Viktoria Swedish ICT: Gothenburg, Sweden, 2014.

25. Shin, J.; Shin, S.; Kim, Y.; Ahn, S.; Lee, S.; Jung, G.; Jeon, S.-J.; Cho, D.H. Design and Implementation of Shaped Magnetic Resonance Based Wireless Power Transfer System for Roadway-Powered Moving Electric Vehicles. IEEE Trans. Ind. Electron. 2014, 61, 1179-1192. [CrossRef]

26. International Commission on Non-Ionizing Radiation Protection. Guidelines for Limiting Exposure to Time-Varying Electric and Magnetic Fields (1 Hz to $100 \mathrm{kHz}$ ). Health Phys. 2010, 99, 818-836.

27. Council of Europe. Resolution 1815-The Potential Dangers of Electromagnetic Fields and Their Effect on the Environment; Council of Europe: Strasbourg, France, 2011; Volume 1815.

28. Covic, G.A.; Boys, J.T. Inductive power transfer. Proc. IEEE 2013, 101, 1276-1289. [CrossRef]

29. Emre, M.; Vermaat, P.; Naberezhnykh, D.; Damousuis, Y.; Theodoropoulos, T.; Cirimele, V.; Doni, A. FABRIC-Review of Existing Power Transfer. Available online: https://www.fabric-project.eu/images/ Deliverables/FABRIC_D33.1_V1_20141215_Review_of_existing_solutions_PUBLIC.pdf (accessed on 7 July 2016).

30. Viktoria Swedish ICT. Slide-in Electric Road System-Conductive Project Report; Viktoria Swedish ICT: Gothenburg, Sweden, 2013.

31. Swedish Transport Agency First Electric Road in Sweden Inaugurated. Available online: http://www. trafikverket.se/en/startpage/about-us/news/2016/2016-06/first-electric-road-in-sweden-inaugurated/ (accessed on 13 February 2018).

32. Broman, G.I.; Robèrt, K.-H. A Framework for Strategic Sustainable Development. J. Clean. Prod. 2017, 140, 17-31. [CrossRef]

33. Robèrt, K.H.; Broman, G.; Waldron, D.; Ny, H.; Byggeth, S.; Cook, D.; Johansson, L.; Oldmark, J.; Basile, G.; Haraldsson, H.; et al. Strategic Leadership towards Sustainability, 6th ed.; Blekinge Institute of Technology: Karlskrona, Sweden, 2010.

34. Missimer, M. Social Sustainability within the Framework for Strategic Sustainable Development; Blekinge Institute of Technology: Karlskrona, Sweden, 2015.

35. Ny, H.; MacDonald, J.P.; Broman, G.; Yamamoto, R.; Robert, K.-H. Sustainability Constraints as System Boundaries: An Approach to Making Life-Cycle Management Strategic. J. Ind. Ecol. 2006, 10, 61-77. [CrossRef]

36. ISO. ISO 14040:2006: Environmental Management, Life Cycle Assessment_Principles and Framework; ISO: Geneva, Switzerland, 2006.

37. Wernet, G.; Bauer, C.; Steubing, B.; Reinhard, J.; Moreno-Ruiz, E.; Weidema, B. The ecoinvent database version 3 (part I): Overview and methodology. Int. J. Life Cycle Assess. 2016, 21, 1218-1230. [CrossRef]

38. Goedkoop, M.; Heijungs, R.; Huijbregts, M.; De Schryver, A.; Struijs, J.; van Zelm, R. ReCiPe 2008: A life Cycle Impact Assessment Method Which Comprises Harmonised Category Indicators at the Midpoint and the Endpoint Level; Ministry of Housing, Spatial Planning and Environment (VROM): Den Haag, The Netherlands, 2013.

39. Tsydenova, O.; Bengtsson, M. Chemical hazards associated with treatment of waste electrical and electronic equipment. Waste Manag. 2011, 31, 45-58. [CrossRef] [PubMed] 
40. Northey, S.; Mohr, S.; Mudd, G.M.; Weng, Z.; Giurco, D. Modelling future copper ore grade decline based on a detailed assessment of copper resources and mining. Resour. Conserv. Recycl. 2014, 83, 190-201. [CrossRef]

41. Harmsen, J.H.M.; Roes, A.L.; Patel, M.K. The impact of copper scarcity on the efficiency of 2050 global renewable energy scenarios. Energy 2013, 50, 62-73. [CrossRef]

42. Elshkaki, A. An analysis of future platinum resources, emissions and waste streams using a system dynamic model of its intentional and non-intentional flows and stocks. Resour. Policy 2013, 38, 241-251. [CrossRef]

43. Blyth, W.; Gross, R.; Speirs, J.; Sorrell, S.; Nicholls, J.; Dorgan, A.; Hughes, N. Low Carbon Jobs: The Evidence for Net Job Creation from Policy Support for Energy Efficiency and Renewable Energy; UKERC: London, UK, 2014.

44. Cambridge Econometrics. Employment Effects of Selected Scenarios from the Energy Roadmap 2050 Final Report for the European Commission (DG Energy); Cambridge Econometrics: Cambridge, UK, 2013.

45. European Commisssion Directive 2008/98/EC of the European Parliament and of the Council of 19 November 2008 on Waste and Repealing Certain Directives. 2008. Available online: http://eur-lex. europa.eu/legal-content/EN/TXT/?uri=CELEX:32008L0098 (accessed on 10 April 2018).

46. Swedish Transport Administration. Swedish Transport Administration Climate Calculation-The Swedish Transport Administration's Model for Calculating the Climate Change Impact and Energy Use of Infrastructure from a Life Cycle Perspective; Version: 3.0; Swedish Transport Administration: Borlänge, Sweden, 2015.

47. Stripple, H.; Uppenberg, S. Life Cycle Assessment of Railways and Rail Transports; IVL Report B1943; Swedish Transport Administration: Luleå, Sweden, 2010.

48. Uppenberg, S. Comparative Life Cycle Assessment for Alternative Design of Electrification for Rail Systems [in Swedish: Jämförande Livscykelanalys för Alternativ Utformning av Hjälpkraft för Spåranläggning]; Swedish Transport Administration: Luleå, Sweden, 2012.

49. Ecoinvent Allocation Cut-off by Classification. Available online: http://www.ecoinvent.org/database/ system-models-in-ecoinvent-3/cut-off-system-model/allocation-cut-off-by-classification.html (accessed on 7 July 2016).

50. Transport and Mobility Leuven TREMOVE Economic Transport and Emissions Model v.2.7b. Available online: http:/ / www.tmleuven.be/methode/tremove/home.htm (accessed on 7 July 2016).

51. Gustafsson, M.; Blomqvist, G.; Håkansson, K.; Lindeberg, J.; Nilsson-Påledal, S. Railway Pollution—Sources, Fate and Actions. [In Swedish: Järnvägens Föroreningar- källor, Spridning och Åtgärder]; VTI: Linköping, Sweden, 2007.

52. Robèrt, K.H.; Borén, S.; Ny, H.; Broman, G. A strategic approach to sustainable transport system development-Part 1: Attempting a generic community planning process model. J. Clean. Prod. 2017, 140, 53-61. [CrossRef]

53. Borén, S.; Nurhadi, L.; Ny, H.; Robèrt, K.H.; Broman, G.; Trygg, L. A strategic approach to sustainable transport system development-Part 2: The case of a vision for electric vehicle systems in southeast Sweden. J. Clean. Prod. 2017, 140, 62-71. [CrossRef]

(C) 2018 by the authors. Licensee MDPI, Basel, Switzerland. This article is an open access article distributed under the terms and conditions of the Creative Commons Attribution (CC BY) license (http:// creativecommons.org/licenses/by/4.0/). 